\title{
Sleep-Related Eating Disorder Caused by Zolpidem: Case Report and Review of the
}

\section{Literature}

Carmen Maura Carrillo de Albornoz ${ }^{1 \oplus}$ Margarita Guerrero-Jiménez ${ }^{10}$, Luis Gutiérrez-Rojas ${ }^{10}$

'Complejo Hospitalario Granada, Psychiatric Service, Servicio Andaluz de Salud, Granada - Spain

\section{ABSTRACT}

Sleep-related eating disorder caused by zolpidem: case report and review of the literature

Sleep-related eating disorder (SRED) is a status characterized by recurrent episodes of eating high caloric foods and sometimes even toxic products at the transition from night-time sleep to arousal. The case presented is secondary to treatment with zolpidem, a hypnotic whose prescription rate has increased worldwide over the past few years. The authors report a case of SRED caused by zolpidem with important repercussions on the sleep structure and quality of life of our patient. The night eating episodes ceased promptly with zolpidem discontinuation, the sleep structure improved and the day- and night-time consequences disappeared. As in very few reported cases of zolpidem-induced SREDs, our patient had been suffering from parasomnia for a long time before the diagnosis. Reaching an understanding of the mechanism producing this type of parasomnias can be a guide for choosing the candidate profile before starting a zolpidem treatment. Active exclusion of symptoms suggestive of SREDs in patients under zolpidem treatment can avoid a significant deterioration in the quality of life of our patients. To our knowledge, there are no data focusing on the risk of parasomnias as a function of the sedative-hypnotic agent chosen. Here we present a case that may help address this issue.

Keywords: Eating disorders, hypnotics, parasomnias, sleep disorders, zolpidem

\section{öz}

Zolpidemin neden olduğu uyku ilişkili yeme bozukluğu: Olgu bildirimi ve literatür derlemesi

Uyku ilişkili yeme bozukluğu (UiYB), gece uykusundan uyanmaya geçiş bölümünde tekrarlayan, yüksek kalorili gıdalar ve hatta bazen toksik ürünler yeme epizodları ile karakterize bir durumdur. Burada sunulan olgu, son yıllarda tüm dünyada reçetelenme oranları artan bir hipnotik ilaç olan zolpidem ile tedavi sonrasında meydana gelmiştir. Yazarlar, hastamızın uyku yapısı ve yaşam kalitesini önemli şekilde etkileyen ve zolpidemden kaynaklanan bir UiYB olgusu bildirmektedir. Gece yeme epizodları zolpidemin kesilmesiyle birlikte ani bir şekilde sonlanmış, uyku yapısı iyileşmiş ve gündüz ile gece olayları ortadan kalkmıştır. Zolpidem ile indüklenen çok az sayıda UiYB olgusunda bildirildiği üzere, bizim hastamız da tanıdan önce uzun bir süre boyunca parasomni yakınmasına sahiptir. Bu tip parasomnileri ortaya çıkaran mekanizmanın daha iyi anlaşılması, zolpidem tedavisine başlanacak aday hasta profilini belirlemede yol gösterici olabilir. Zolpidem tedavisi alan hastalarda UiYB'yi düşündüren belirtilerin aktif bir şekilde dışlanması hastalarımızın yaşam kalitesinde yaşanabilecek anlamlı bir kötüleşmeyi önleyebilir. Bildiğimiz kadarılla, literatürde seçilen sedatifhipnotik ajanın bir işlevi olarak parasomni riskine odaklanan bir veri yoktur. Biz bu yazıda ilgili konuyu ele alan bir olgu sunuyoruz.

Anahtar kelimeler: Yeme bozuklukları, hipnotikler, parasomniler, uyku bozuklukları, zolpidem

How to cite this article: Carrillo de Albornoz CM, Guerrero-Jiménez L, Gutiérrez-Rojas L. Sleep-related eating disorder caused by zolpidem: case report and review of the literature. Dusunen Adam The Journal of Psychiatry and Neurological Sciences 2018;31:195-200

https://doi.org/10.5350/DAJPN2018310207

Address reprint requests to / Yazışma adresi: Luis Gutiérrez-Rojas,

Calle Jimena $n^{\circ} 13,2^{\circ}$ B, Granada, Spain

Phone / Telefon: +34-958-17-0312

E-mail address / Elektronik posta adresi: gutierrezrojasl@hotmail.com

Date of receipt / Geliş tarihi: November 9, 2017 / 9 Kasım 2017

Date of the first revision letter / ilk düzeltme öneri tarihi:

November 27, 2017 / 27 Kasım 2017

Date of acceptance / Kabul tarihi: December 16, 2017 / 16 Aralık 2017 


\section{INTRODUCTION}

For years, anxiolytics and hypnotics have been one - of the most prescribed drug classes in most developed countries (1). In fact, several studies (2) have shown that the consumption of these drugs has increased considerably and steadily in Spain according to the most recent analysis.

The latest analysis suggests that Spain is found above the European average in consumption of anxiolytics (3). In a recent survey of drug abuse, it has been estimated that the prevalence of sedative hypnotics in Spain in 2011 was 11.4\% in the general population (4).

Zolpidem (ZPD) is a sedative-hypnotic agent with a chemical structure unrelated to those of benzodiazepines, barbiturates, pyrazolopyrimidines, or other drugs with known hypnotic properties. It mainly modulates the $\gamma$-aminobutyric acid A receptor $\alpha$ subunit, which is hypothesized to be responsible for sedative, anticonvulsant, and anxiolytic drug properties. Its rapid action, short half-life, reduced side effects when compared to other benzodiazepines or barbiturates, and lower potential for abuse and dependence justify its widespread use today.

Several cases have been reported in which sleeprelated eating disorders (SREDs) were associated with ZPD (5,6). According to the International Classification of Sleep Disorders, Second Edition (7) SRED is classified as parasomnia and characterized by recurrent episodes of involuntary eating and drinking in the middle of main sleep periods with problematic consequences. Here, we present an extremely rare case of a patient who developed compulsive evening eating behavior because of ZPD treatment. The patient showed complete remission after ZPD treatment was stopped.

\section{CASE}

We present the case of a 58-year-old white female who was referred to a Community Mental Health Unit by a primary care physician. Her informed consent to use her clinical documentation for publication was obtained. She reported no organic medical history of interest or drug allergies and had not had previous contacts with Mental Health Services or any psychiatric family history. She worked as a household cleaner and as a commercial dietician in a dietary supplement business.

The patient has two independent children of 27 and 32 years with whom she maintains good relations and two grandchildren of one and two years. They all live nearby and they visit one other daily. She denies current or past use of intoxicants. Sporadically she drinks a beer at a family celebration. Eight months ago, her 60-year-old husband had died suddenly one morning while sleeping next to her.

Our patient reports intense anguish associated mainly to situations of solitude and moments of rumination about the event that she has been experiencing since then. The patient presents clinically with apathy-abulia, affective lability, anhedonia, and mainly conciliation insomnia. For the consultation, she is accompanied by her daughter. She has an adequate general appearance, is neatly dressed and wearing makeup, is calm and cooperative.

The patient is conscious, oriented in time, space and person, cooperative during the interview from the first contact. She shows important affective lability during the interview and a tendency to spontaneous crying. Cognitive anxiety is evident in the background, related mainly to memories of her husband and the event of his death. Her speech is focused on the anguish derived from the moments of solitude at home and the anhedonia that accompanies it due to the event. There is no evidence of alterations in the form, course, or content of thought or sense perception. She reports accompanying conciliatory insomnia and hyporexia with weight loss of approximately $5 \mathrm{~kg}$ and has a correct awareness of illness and need for treatment.

She provides a general analysis with hemogram, biochemistry, coagulation, serology, and thyroid profile with findings within the normal range. A basic cardiorespiratory and neurological examination is performed that is also within the normal range. The patient does not suffer any physical complaints at the time of the examination. 
We diagnosed an adaptive disorder and started treatment with escitalopram (icreased to $20 \mathrm{mg}$ daily dose) and ZPD $10 \mathrm{mg}$ to be taken at night and made a referral to psychology consultation for brief supporting psychotherapy.

We revisited her after 4 weeks for a reevaluation, which was satisfactory, with an acceptable affective and insomnia improvement, and we referred her back to Primary Care assistance.

Eight weeks later, we received a call from a primary care doctor asking about this patient: "She is gaining a lot of weight (approximately $7 \mathrm{~kg}$ since the beginning of the treatment). She says that she gets out of her bed which is full of candy containers, fruit peels, nuts... food she claims she did not prefer before. She also reported a feeling of fullness when getting up that prevents her from having breakfast in the mornings.

She started to think that someone had come to steal from the home and got up scared. She started to close the door with several locks. At first we thought this was secondary to her anxiety but she was mentally much better and she was not aware of her eating.

After a literature review on possible side effects of the medication, we contacted her primary care physician again to withdraw treatment with ZPD $10 \mathrm{mg}$ and treat her with lormetazepam $2 \mathrm{mg}$ in the evening instead. Patient's symptoms ceased in 3 days after ZPD discontinuation.

\section{DISCUSSION}

Sleep-related eating disorders (SREDs) were first described in 1991 by Schenck et al. (8), establishing a new entity, distinct from the already known 'nighteating syndrome' (NES). Prevalence in the general population is not well established, but it is estimated to be between $1 \%$ and $5 \%$ in adults, even reaching $16.7 \%$ (9). In patients with eating disorders, the most commonly underdiagnosed subtype is sleep-related eating disorders (SREDs), which are characterized by recurrent episodes of binge eating in mid-sleep, diurnal anorexia or significant weight gain. They occur frequently during the first half of the night. Patients usually eat high-calorie food, including sometimes unusual food combinations such as cologne, cigarettes, or some toxic home-made products. SREDs are more common in young adults, with a predominance of females. These symptoms tend to become chronic by clinical ignorance and may reach a chronic course with important physical repercussions such as the need for bariatric surgery or injuries resulting from food preparation such as burns or knife wounds.

The pathophysiology of SRED is unknown. Different theories are posited including a sleep-wake boundary dysfunction. Firstly, phenomena that deepen sleep and enhance sleep inertia may promote NREM (non-rapid eye movement) parasomnia by impairing otherwise normal arousal mechanisms. Secondly, conditions that cause repeated cortical arousals (sleep fragmentation) may lead to NREM parasomnia as ZPD does (10).

Another possible mechanism is that the circadian rhythm of eating is delayed relative to the sleep-awake rhythm. There is a temporal redistribution of daily energy intake with consumption of food both before going to bed and during midnight awakenings. Phase delays in the circadian rhythm of the secretion of hormones, including leptin, insulin, and melatonin, have been demonstrated in these patients $(11,12)$.

Finally, SRED may have a genetic predisposition as described in the study by Winkelman (9) suggesting that approximately $20 \%$ of their SRED cases showed familial aggregation of the disorder. ZPD stimulated the patients' brain in the vegetative state and caused them to wake up for short periods. In addition, ZPD may induce parasomnias and increase NREM sleep. Thus these properties increase risk of somnambulistic behaviors. Another hypothesis is that ZPD induces a lack of inhibition or hallucinations with amnesia (13).

The combination of causes that contribute to sleep fragmentation with induced hyperphagic response could be a plausible hypothesis to explain this disorder (14). Some authors have considered ZPDrelated behaviors as somnambulism, while others regard them as compulsive activities with anterograde amnesia, different from somnambulism (15). Finally, it has been speculated that an eating disorder, with poor impulse control, could become amnesic with 
Table 1: Articles that include case reports of SREDs secondary to zolpidem

\begin{tabular}{|c|c|c|c|c|c|c|}
\hline Case & $\begin{array}{l}\text { Age of onset/ } \\
\text { Gender }\end{array}$ & $\begin{array}{l}\text { Dosage } \\
(\mathrm{mg})\end{array}$ & $\begin{array}{l}\text { Symptom } \\
\text { onset }\end{array}$ & $\begin{array}{l}\text { Psychiatric } \\
\text { comorbidities }\end{array}$ & Concomitant treatment & $\begin{array}{l}\text { SRED cessation } \\
\text { following } \\
\text { zolpidem } \\
\text { discontinuation }\end{array}$ \\
\hline \multirow[t]{5}{*}{ Morgenthal and Silber 2002 (5) } & $51 / \mathrm{F}$ & 10 & 3 weeks after & No & Carbidopa/levodopa, paroxetine & Yes \\
\hline & $65 / \mathrm{M}$ & 10 & Soon after & Parkinson's disease & Trazodone, ropinerole, fluoxetine & Yes \\
\hline & $41 / \mathrm{M}$ & $15-30$ & NA & NA & Alprazolam, bupropion & Yes \\
\hline & $64 / \mathrm{M}$ & $5-10$ & NA & NA & Amitriptyline, gabapentin & Yes \\
\hline & $56 / \mathrm{F}$ & $5-10$ & NA & NA & Pramipexole & Yes \\
\hline Najjar 2007 (6) & $46 / \mathrm{F}$ & 6.25 & 3 weeks after & Depression & Trazodone, paroxetine & Yes \\
\hline \multirow[t]{2}{*}{ Chiang and Krystal 2000 (17) } & $75 / \mathrm{F}$ & $12.5+$ & Soon after & No & Gabapentin & Yes \\
\hline & $70 / \mathrm{F}$ & $12.5+$ & Soon after & No & Pramipexole, gabapentin & Yes \\
\hline Hoque and Chesson 2009 (18) & $44 / \mathrm{F}$ & 10 & Few weeks & Depression & Paroxetine & Yes \\
\hline Dang et al. 2009 (19) & $45 / \mathrm{M}$ & 10 & 10 days after & No & No & Yes \\
\hline Miranda et al. 2010 (20) & $49 / \mathrm{M}$ & 10 & 4 months & Bipolar Disorder & Lamotrigine, clonazepam & Yes \\
\hline Yun and Ji. 2010 (21) & $45 / \mathrm{M}$ & 10 & 6 months & No & No & Yes \\
\hline \multirow[t]{5}{*}{ Perez-Diaz et al. 2010 (22) } & $39 / \mathrm{F}$ & 20 & 6 months after & Major Depression & Fluoxetine & Yes \\
\hline & $55 / \mathrm{F}$ & 10 & 9 years after & Major Depression & Fluoxetine & Yes \\
\hline & $53 / \mathrm{F}$ & 10 & 'Few weeks' & Major Depression & Velanfaxin, alprazolan & Yes \\
\hline & 79/F & 10 & 3 years after & Dysthymia & No & Yes \\
\hline & $27 / M$ & 10 & 2 months & $\begin{array}{l}\text { Sporadic use of } \\
\text { drugs of abuse }\end{array}$ & No & Yes \\
\hline Nzwalo et al. 2013 (23) & $53 / \mathrm{F}$ & 10 & 5 years & No & No & Yes \\
\hline Kim et al. 2013 (24) & $57 / \mathrm{F}$ & 10 & Soon after & NA & $\begin{array}{l}\text { Diazepam, lorazepam, } \\
\text { quetiapine, escitalopram }\end{array}$ & Yes \\
\hline Park et al. 2016 (25) & $71 / \mathrm{M}$ & 12.5 & Soon after & NA & Pramipexole, lorazepam & Yes \\
\hline Actual case 2017 & $58 / \mathrm{F}$ & 10 & 12 weeks & Adaptive disorder & Escitalopram & Yes \\
\hline
\end{tabular}

F: Female; M: Male, NA: Not Available, SRED: Sleep-Related Eating Disorder

ZPD, thereby explaining the SRED. We must mention the transformation of a nocturnal eating syndrome into an amnesic one as a result of the use of ZPD (5). Unlike what occurs in nocturnal eating syndrome, patients present partial or complete amnesia of these episodes. Complex behaviors during sleep have been associated with various drugs such as tricyclics or anticholinergics, with food being mostly related to ZPD. The withdrawal of the drug immediately resolves these parasomnias.

We searched the PubMed database for reported cases of ZPD-related eating disorders. We found 11 articles using the search terms "zolpidem" and "eating and sleep" (Table 1). In all of them, the sleep-related eating disorder ceased after ZPD discontinuation as in our actual case. Our case is among one of those reviewed in which the hyperphagic clinical picture began more quickly and, as happened in the other cases reviewed, disappeared as soon as the hypnotic was withdrawn.

The U.S. Food and Drug Administration recently requested that manufacturers of sedative-hypnotics enhance their product labeling to include stronger language concerning potential risks of parasomnias, such as nocturnal eating (16).

In the reviewed literature, most of the cases were associated with other pathologies, the most prevalent cases of which were obesity, restless leg syndrome, or somnambulism. One of the most interesting and novel aspect of our case is the absence of these concomitant pathologies. 
There are many negative side effects of this syndrome in the general population, hence our interest in reviewing the published literature. The most frequently described consequence is undesired weight gain due to the consumption of foods with high caloric content during the night. Affective consequences of this unwanted gain of weight are linked with an important anguish derived and feelings of "lack of control", shame, guilt, and impotence in the face of nocturnal binge eating.

It is also interesting to highlight a significant daytime fatigue in these patients due to a disruption of their night rest, a fact that interrupts their daily activities and leads to a decline in their quality of life. Finally, we need to point out that accidents may result from the reduced alertness during the behavior episodes that could endanger the lives of our patients due to events such as falls, accidents or burns.

\begin{tabular}{|l|l|l|}
\hline \multicolumn{2}{|l|}{ Contribution Categories } & Author Initials \\
\hline \multirow{4}{*}{ Category 1} & Concept/Design & C.C.A., M.G.J. \\
\cline { 2 - 3 } & Literature review & C.C.A., M.G.J., L.G.R. \\
\cline { 2 - 3 } & Data analysis/Interpretation & L.G.R. \\
\cline { 2 - 3 } & Case follow-up (if applicable) & C.C.A., M.G.J. \\
\hline \multirow{3}{*}{ Category 2} & Drafting manuscript & C.C.A., M.G.J. \\
\cline { 2 - 3 } & Critical revision of manuscript & L.G.R. \\
\hline Category 3 & Final approval and accountability & C.C.A., M.G.J., L.G.R. \\
\hline \multirow{3}{*}{ Other } & Technical or material support & N/A \\
\cline { 2 - 3 } & Supervision & N/A \\
\cline { 2 - 3 } & Securing funding (if applicable) & N/A \\
\hline
\end{tabular}

Informed Consent: Written consent was obtained from the patient.

Peer-review: Externally peer-reviewed.

Conflict of Interest: Dr. Gutiérrez-Rojas reports personal fees and non-financial support from Janssen, personal fees and nonfinancial support from Pfizer, personal fees and non-financial support from Otsuka, personal fees and non-financial support from Servier, personal fees and non-financial support from Lundbeck, outside the submitted work.

Dr. Jiménez-Guerrero and Dr. Carrillo de Albornoz declared no conflict of interest.

Financial Disclosure: Authors declared no financial support.

6. Najjar M. Zolpidem and amnestic sleep related eating disorder. J Clin Sleep Med 2007; 3:637-638.

7. American Academy of Sleep Medicine. The international classification of sleep disorders: diagnostic and coding manual. Second ed. Westchester, IL: American Academy of Sleep Medicine 2005: XVIII, 297.

8. Schenck CH, Hurwitz TD, Bundlie SR, Mahowald MW. Sleeprelated eating disorders: polysomnographic correlates of a heterogeneous syndrome distinct from daytime eating disorders. Sleep 1991; 14:419-431. [CrossRef]

9. Winkelman JW, Herzog DB, Fava M. The prevalence of sleeprelated eating disorder in psychiatric and non-psychiatric populations. Psychol Med 1999; 29:1461-1466. [CrossRef]

10. Parrino L, Halasz P, Tassinari CA, Terzano MG. CAP, epilepsy and motor events during sleep: the unifying role of arousal. Sleep Med Rev 2006; 10:267-285. [CrossRef] 
11. Vetrugno R, Manconi M, Ferini-Strambi L, Provini F, Plazzi G, Montagna P. Nocturnal eating: sleep-related eating disorder or night eating syndrome? A videopolysomnographic study. Sleep 2006; 29:949-954. [CrossRef]

12. Birketvedt GS, Florholmen J, Sundsfjord J, Osterud B, Dinges D, Bilker W, Stunkard A. Behavioral and neuroendocrine characteristics of the night-eating syndrome. JAMA 1999; 282:657-663. [CrossRef]

13. Le Bon $\mathrm{O}$, Neu $\mathrm{D}$. Total absence of recall of discussion occurred shortly after ingestion of $10 \mathrm{mg}$ zolpidem. Pharmacopsychiatry 2009; 42:126-127. [CrossRef]

14. Filizola M, Harris DL, Loew GH. Benzodiazepine-induced hyperphagia: development and assessment of a 3D pharmacophore by computational methods. J Biomol Struct Dyn 2000; 17:769-778. [CrossRef]

15. Tsai MJ, Tsai YH, Huang YB. Compulsive activity and anterograde amnesia after zolpidem use. Clin Toxicol 2007; 45:179-181. [CrossRef]

16. FDA requests label change for sleep disorder drug products. FDA News, March 14, 2007.

17. Chiang A, Krystal A. Report of two cases where sleep related eating behavior occurred with the extended-release formulation but not the immediate-release formulation of a sedative-hypnotic agent. J Clin Sleep Med 2008; 4:155-156.
18. Hoque R, Chesson AL Jr. Zolpidem-induced sleepwalking, sleep related eating disorder, and sleep-driving: fluorine-18flourodeoxyglucose positron emission tomography analysis, and a literature review of other unexpected clinical effects of zolpidem. J Clin Sleep Med 2009; 5:471-476.

19. Dang A, Garg G, Rataboli PV. Zolpidem induced Nocturnal Sleep-Related Eating Disorder (NSRED) in a male patient. Int J Eat Disord 2009; 42:385-386. [CrossRef]

20. Miranda M, Seijas D, Castillo JL, Pérez JC. Zolpidem induced sleep related eating disorder. Rev Med Chil 2010; 138:10671069. (Spanish)

21. Yun $\mathrm{CH}$, Ji KH. Zolpidem-induced sleep-related eating disorder. J Neurol Sci 2010; 288:200-201. [CrossRef]

22. Pérez-Díaz H, Iranzo A, Santamaría J. Zolpidem-induced sleeprelated behavioural disorders. Neurología (English Edition) 2010; 25:491-497. [CrossRef]

23. Nzwalo H, Ferreira L, Peralta R, Bentes C. Sleep-related eating disorder secondary to zolpidem. BMJ Case Rep 2013; 2013.

24. Kim HK, Kwon JT, Baek J, Park DS, Yang KI. Zolpidem-induced compulsive evening eating behavior. Clin Neuropharmacol 2013; 36:173-174. [CrossRef]

25. Park YM, Shin HW. Zolpidem induced sleep-related eating and complex behaviors in a patient with obstructive sleep apnea and restless legs syndrome. Clin Psychopharmacol Neurosci 2016; 14:299-301. [CrossRef] 